\title{
Technical and Economic Analysis on Ground Source Heat Pump Air Conditioning System in the Hotel as an Example
}

\author{
Di Li \\ Dept. of Green building Research Shandong Provincial \\ Academy of Building Research \\ Ji Nan 250031, China \\ 18653164200@163.com \\ Songshi Liu \\ Dept. of structure engineering Shandong Provincial \\ Academy of Building Research \\ Ji Nan 250031, China \\ 153513947@qq.com
}

\begin{abstract}
This essay demonstrate the application of ground source heat pump air conditioning system in a hotel, and also test the performance of heat pump units and the heat pump air conditioning system. According to the test results, to analyze and evaluate the energy saving property and economy of the system providing reference for other similar applications.
\end{abstract}

Key Words: Ground source heat pump; system's energy efficiency ratio; comprehensive evaluation

\section{I .Introduction}

The renewable energy in construction application is one of the six largest fields in building energy saving potential in China. It is strategic core and advance position of building energy saving and emission reduction. Renewable energy in construction application and popularization in Shandong Province is fast. 19 renewable energy in construction application demonstration cities (counties and districts) and 34 renewable energy in construction application demonstration projects in Shandong Province have been approved since 2006. Up to the end of 2010, construction application area of ground source heat pump air conditioning system in Shandong Province reached 8 million $\mathrm{m}^{2}$. It is proposed in "The $12^{\text {th }}$ Five-Year" Plan for Saving Energy in Shandong Province that we have to actively promote geothermal utilization and actively popularize geothermal heating and heating water technology and product which can meet the requirements of environmental protection and water resource protection through strengthening financial fund guide and demonstration drive; construct a batch of significant demonstration projects in ground source heat pump application. By 2015, construction application area of ground source heat pump air conditioning system will

\author{
Suiqi Han \\ Dept. of Green building Research Shandong Provincial \\ Academy of Building Research \\ Ji Nan 250031, China \\ hfeng008@163.com \\ Ting Wang \\ Dept. of Human Resources Shandong Provincial Academy \\ of Building Research \\ Ji Nan 250031, China \\ 33008501@qq.com
}

reach 30 million $\mathrm{m}^{2}$.

Some problems appear to the renewable energy in construction application during promotion. The main reflection of ground source heat pump air conditioning system is lacking of comprehensive evaluation system and strict market access system and unable to carry out evaluation of the system reliability and energy saving effect effectively. Therefore, the country attaches great importance to acceptance of renewable energy in construction application. It formulates and issues Evaluation Guide of Renewable Energy in Construction Application Demonstration Project and Technical Guide of Data Monitoring System of Renewable Energy in Construction Application Demonstration Project successively so as to guide project acceptance ${ }^{[1-3]}$. At present, the acceptance of application project in renewable energy in construction application demonstration city (county) in Shandong Province has been started. The evaluation results of the project may provide reference to similar projects in Shandong Province and promote rapid and sound development of building energy saving.

\section{II . Project overview}

The hotel is a five-star hotel. It is a large public building which integrates hotel, large meeting, catering, entertainment and office. Total building area of the hotel is $43400 \mathrm{~m}^{2}$.

Ground source heat pump technology is used as cold and heat source of heating air conditioning system of the whole hotel in the project. Meanwhile, heat recovery technology is used for providing hot water for bathing to the hotel in the system. Three Xiaite screw ground source heat pump units are selected for air conditioning system in the project. Maximum refrigerating capacity in summer is $3014 \mathrm{~kW}$; maximum heating capacity in winter is $3690 \mathrm{~kW}$. 


\section{III.Performance test results of heat pump air conditioning system}

The acceptance team carried out evaluation of heating and refrigeration performance of ground source heat pump air conditioning in the project in March and June 2011. Test content mainly includes: indoor temperature and humidity; heating COP and refrigeration COP of heat pump unit; heating energy efficiency ratio and refrigeration energy efficiency ratio of heat pump air conditioning system ${ }^{[4]}$. The specific test method is carried out according to Evaluation Guide of Renewable Energy in Construction Application Demonstration Project.

\section{A. Indoor test results}

Make sure to carry out evaluation of all kinds of performance of ground source heat pump air conditioning heating system on the premise of meeting comfort requirement. Thus, it needs to implement one cycle (24h) of monitoring for indoor temperature and humidity used for typical terminal of the system when implementing test for ground source heat pump air conditioning system performance. Carry out test for indoor temperature and humidity in three rooms. The test results are shown in Table 1.

Table 1 Test Results of Indoor Temperature and Humidity in Air-conditioning Room through Sample Test

\begin{tabular}{|c|c|c|c|}
\hline Room No. & $\begin{array}{c}\text { Average } \\
\text { temperature in } \\
\text { summer }{ }^{\circ} \mathrm{C}\end{array}$ & $\begin{array}{c}\text { Average relative } \\
\text { humidity in } \\
\text { summer \% }\end{array}$ & $\begin{array}{c}\text { Average } \\
\text { temperature in } \\
\text { winter }{ }^{\circ} \mathrm{C}\end{array}$ \\
\hline 806 & 24.4 & 52.5 & 22.4 \\
\hline 1806 & 21.5 & 62.4 & 24.8 \\
\hline 2106 & 20.8 & 58.8 & 24.5 \\
\hline
\end{tabular}

The design temperature in air-conditioning room in summer is $25^{\circ} \mathrm{C}$; the humidity in air-conditioning room in summer shall be $40 \% \sim 65 \%$; the design temperature in air-conditioning room in winter is $20{ }^{\circ} \mathrm{C}$ according to Design Standard for Energy Efficiency of Public Buildings GB50189-2005. It is shown in Table 1 terminal heating of heat pump air conditioning system and air-conditioning effect is good.

\section{B. Test result of heat pump unit and system performance}

Carry out continuous test ${ }^{[5]}$ for the flow and inlet and outlet water temperature on heat source side of operation system, the flow and inlet and outlet water temperature on system user side, power consumption of all kinds of circulating water pumps, the flow and inlet and outlet water temperature on heat source side of the unit, the flow and inlet and outlet water temperature on user side of the unit and unit input power. Calculate actual operation COP and energy efficiency ratio of heat pump air conditioning system according to test data. The calculation results are shown in Table 2 and Table 3.

Table 2 Measurement Results of Refrigeration COP and Energy Efficiency Ratio of System of Ground Source Heat Pump Unit in Summer

\begin{tabular}{|c|c|c|c|}
\hline \multicolumn{4}{|c|}{ Nameplate content } \\
\hline \multicolumn{3}{|c|}{ Model } & LWP99 \\
\hline \multicolumn{3}{|c|}{ Rated refrigerating capacity $(\mathrm{kW})$} & 889 \\
\hline \multicolumn{3}{|c|}{ Rated refrigerating input power $(\mathrm{kW})$} & 159 \\
\hline \multicolumn{4}{|c|}{ Measurement data } \\
\hline $\begin{array}{lr}\text { Average } & \text { supply } \\
\text { chilled } & \text { water } \\
\text { temperature } t_{1}\left({ }^{\circ} \mathrm{C}\right)\end{array}$ & 9.5 & $\begin{array}{l}\text { Average return chilled } \\
\text { water temperature } t_{2} \\
\left({ }^{\circ} \mathrm{C}\right)\end{array}$ & 13.3 \\
\hline $\begin{array}{l}\text { Average water flow } \\
\text { on user side } V_{1}\left(\mathrm{~m}^{3} / \mathrm{h}\right)\end{array}$ & 182.3 & $\begin{array}{l}\text { Average supply water } \\
\text { temperature on ground } \\
\text { source side } t_{3}\left({ }^{\circ} \mathrm{C}\right)\end{array}$ & 20.3 \\
\hline $\begin{array}{l}\text { Average return water } \\
\text { temperature on } \\
\text { ground source side } t_{4} \\
\left({ }^{\circ} \mathrm{C}\right)\end{array}$ & 24.2 & $\begin{array}{l}\text { Average supply water } \\
\text { temperature of domestic } \\
\text { hot water } t_{5}\left({ }^{\circ} \mathrm{C}\right)\end{array}$ & 50.2 \\
\hline $\begin{array}{l}\text { Average return water } \\
\text { temperature of } \\
\text { domestic hot water } t_{6} \\
\left({ }^{\circ} \mathrm{C}\right)\end{array}$ & 47.1 & $\begin{array}{l}\text { Average flow of } \\
\text { domestic hot water } V_{2} \\
\left(\mathrm{~m}^{3} / \mathrm{h}\right)\end{array}$ & 3.7 \\
\hline $\begin{array}{l}\text { Average power } \\
\text { heat pump unit } \\
N_{1} \\
(\mathrm{~kW})\end{array}$ & 176.3 & $\begin{array}{l}\text { Average power of } \\
\text { circulating water pump } \\
\text { on user side } P_{1}(\mathrm{~kW})\end{array}$ & 6.7 \\
\hline $\begin{array}{l}\text { Average power of } \\
\text { circulating water } \\
\text { pump on ground } \\
\text { source side } P_{2}(\mathrm{~kW})\end{array}$ & 8.9 & $\begin{array}{l}\text { Average power of } \\
\text { circulating water pump } \\
\text { of domestic hot water } \\
P_{3}(\mathrm{~kW})\end{array}$ & 6.6 \\
\hline \multicolumn{4}{|c|}{ Measurement results } \\
\hline \multicolumn{3}{|c|}{ Measured refrigerating capacity of heat pump unit $(\mathrm{kW})$} & 817.7 \\
\hline \multicolumn{3}{|c|}{ Refrigeration COP of heat pump unit $C O P_{\mathrm{L}}$} & 4.64 \\
\hline \multicolumn{3}{|c|}{$\begin{array}{c}\text { Energy efficiency ratio of heat pump air conditioning } \\
\text { system under refrigeration condition } C O P_{\mathrm{SL}}\end{array}$} & 4.12 \\
\hline
\end{tabular}
stem under refrigeration condition $C O P_{\mathrm{SL}}$

1. Refrigerating capacity calculation of heat pump unit: $Q_{0}=\frac{V_{1} \rho c\left(t_{2}-t_{1}\right)}{3600}+\frac{V_{2} \rho c\left(t_{5}-t_{6}\right)}{3600}$

2. Refrigeration COP calculation of heat pump unit:

Notes $C O P_{\mathrm{L}}=\frac{Q_{0}}{N_{1}}$

3. Energy efficiency ratio calculation of heat pump air conditioning system under refrigeration condition: $C O P_{\mathrm{SL}}=\frac{Q_{0}}{N_{1}+P_{1}+P_{2}+P_{3}}$ 
Table 3 Measurement Results of Heating COP and Energy Efficiency Ratio of System of Ground Source Heat Pump Unit in Winter

\begin{tabular}{|c|c|c|c|c|}
\hline \multicolumn{5}{|c|}{ Nameplate content } \\
\hline \multicolumn{4}{|c|}{ Model } & LWP99 \\
\hline \multicolumn{4}{|c|}{ Rated heating capacity (kW) } & 1122 \\
\hline \multicolumn{4}{|c|}{ Rated heating input power $(\mathrm{kW})$} & 223 \\
\hline \multicolumn{5}{|c|}{ Measurement data } \\
\hline \multicolumn{2}{|c|}{$\begin{array}{l}\text { Average supply hot water } \\
\text { temperature of air } \\
\text { conditioning } t_{1}\left({ }^{\circ} \mathrm{C}\right)\end{array}$} & 40.4 & $\begin{array}{l}\text { Average return hot } \\
\text { water temperature of } \\
\text { air conditioning } t_{2} \\
\left({ }^{\circ} \mathrm{C}\right)\end{array}$ & 35.6 \\
\hline \multicolumn{2}{|c|}{$\begin{array}{l}\text { Average water flow on } \\
\text { user side } V_{1}\left(\mathrm{~m}^{3} / \mathrm{h}\right)\end{array}$} & 143.1 & $\begin{array}{lr}\text { Supply } & \text { water } \\
\text { temperature } & \text { on } \\
\text { ground source } & \text { side } t_{3} \\
\left({ }^{\circ} \mathrm{C}\right) & \end{array}$ & 10.0 \\
\hline \multicolumn{2}{|c|}{$\begin{array}{l}\text { Average return } \\
\text { temperature on } \text { water } \\
\text { source side } t_{4}\left({ }^{\circ} \mathrm{C}\right)\end{array}$} & 5.1 & $\begin{array}{l}\text { Average supply water } \\
\text { temperature of } \\
\text { domestic hot water } t_{5} \\
\left({ }^{\circ} \mathrm{C}\right)\end{array}$ & 58.2 \\
\hline \multicolumn{2}{|c|}{$\begin{array}{l}\text { Average return water } \\
\text { temperature of domestic } \\
\text { hot water } t_{6}\left({ }^{\circ} \mathrm{C}\right)\end{array}$} & 52.4 & $\begin{array}{l}\text { Average flow of } \\
\text { domestic hot water } V_{2} \\
\left(\mathrm{~m}^{3} / \mathrm{h}\right)\end{array}$ & 4.1 \\
\hline \multicolumn{2}{|c|}{$\begin{array}{l}\text { Average power of heat } \\
\text { pump unit } N_{1}(\mathrm{~kW})\end{array}$} & 231.0 & $\begin{array}{l}\text { Average power of } \\
\text { circulating water } \\
\text { pump on user side } P_{1} \\
(\mathrm{~kW})\end{array}$ & 18.0 \\
\hline \multicolumn{2}{|c|}{$\begin{array}{l}\text { Average power of } \\
\text { circulating water pump on } \\
\text { ground source side } P_{2} \\
(\mathrm{~kW})\end{array}$} & 20.4 & $\begin{array}{l}\text { Average power of } \\
\text { circulating water } \\
\text { pump of domestic hot } \\
\text { water } P_{3}(\mathrm{~kW}) \\
\end{array}$ & 7.6 \\
\hline \multicolumn{5}{|c|}{ Measurement results } \\
\hline \multicolumn{4}{|c|}{ Measured heating capacity of heat pump unit (kW) } & 825.4 \\
\hline \multicolumn{4}{|c|}{ Heating COP of heat pump unit $C O P_{\mathrm{H}}$} & 3.57 \\
\hline \multicolumn{4}{|c|}{$\begin{array}{l}\text { Energy efficiency ratio of heat pump air conditioning } \\
\text { system under heating condition } C O P_{\mathrm{SH}}\end{array}$} & 2.98 \\
\hline \multirow{3}{*}{ Notes } & \multicolumn{4}{|c|}{$\begin{array}{l}\text { 1. Heating capacity calculation of heat pump unit: } \\
Q_{0}=\frac{V_{1} \rho c\left(t_{1}-t_{2}\right)}{3600}+\frac{V_{2} \rho c\left(t_{5}-t_{6}\right)}{3600}\end{array}$} \\
\hline & \multicolumn{4}{|c|}{$\begin{array}{l}\text { 2. Heating COP calculation of heat pump unit: } \\
\mathrm{COP}_{\mathrm{H}}=\frac{Q_{0}}{N_{1}}\end{array}$} \\
\hline & \multicolumn{4}{|c|}{$\begin{array}{l}\text { 3. Energy efficiency ratio calculation of heat pump air } \\
\text { conditioning system under heating condition: } \\
\mathrm{COP}_{\mathrm{SH}}=\frac{Q_{0}}{N_{1}+P_{1}+P_{2}+P_{3}}\end{array}$} \\
\hline
\end{tabular}

\section{IV.Technical and economic analysis of the project}

The main content of technical and economic analysis of the project includes conventional energy substitution amount, annually saving amount and payback period of static investment.

\section{A. Calculation of annual heat consumption and annual refrigeration consumption}

In winter, calculate annual heat consumption in heating season with degree-day method according to measured heating capacity of the system and outdoor meteorological parameters during test period. The calculation of annual heat consumption in heating season is shown in the following formula ${ }^{[6]}$ :

Where:

$$
Q_{h}=\frac{t_{i}-t_{y p j}+\Delta t}{t_{i}-t_{d p j}+\Delta t} \times Q_{c} \times Z(1)
$$

$Q_{h}$ —Annual heat consumption in heating season $(\mathrm{kW} \cdot \mathrm{h})$;

$t_{i}$ — Indoor reference temperature $\left({ }^{\circ} \mathrm{C}\right)$; it is $18^{\circ} \mathrm{C}$;

$t_{y p j}$ Outdoor average temperature in heating season $\left({ }^{\circ} \mathrm{C}\right)$; it is $-0.80^{\circ} \mathrm{C}$;

$t_{d p j}$ Outdoor average temperature on test day $\left({ }^{\circ} \mathrm{C}\right)$; it is $9.1^{\circ} \mathrm{C}$;

$\Delta t$ - Difference between indoor measured temperature and indoor reference temperature $\left({ }^{\circ} \mathrm{C}\right)$, indoor measured average temperature during the test is $23.9^{\circ} \mathrm{C}$;

$Q_{c}$ - Accumulative heating load in test period $(\mathrm{kW} \cdot \mathrm{h})$, it is $19809.6 \mathrm{~kW} \cdot \mathrm{h}$;

\section{$Z$ - Heating days, it is 113 days.}

Annual heat consumption of the project is calculated according to Formula (1).

$Q_{h}=\frac{t_{i}-t_{y p j}+\Delta t}{t_{i}-t_{d p j}+\Delta t} \times Q_{c} \times Z=\frac{18+0.8+5.9}{18-9.1+5.9} \times 19809.6 \times 113=$ $3735850 \mathrm{~kW} \cdot \mathrm{h}$

In summer, calculate annual refrigeration consumption in cooling season with BIN method according to measured refrigerating capacity of the system and outdoor meteorological parameters during test period.

BIN parameters in target city are shown in Table 4 based on meteorological parameters in target City through taking $2{ }^{\circ} \mathrm{C}$ temperature difference as one temperature frequency band.

Table 4 BIN Meteorological Parameters in target city

\begin{tabular}{|c|c|c|c|c|c|c|c|}
\hline $\mathrm{BIN} /{ }^{\circ} \mathrm{C}$ & 24 & 26 & 28 & 30 & 32 & 34 & 36 \\
\hline $\begin{array}{c}\text { Time } \\
\text { frequency/h }\end{array}$ & 472 & 507 & 400 & 252 & 126 & 46 & 16 \\
\hline
\end{tabular}

When outdoor temperature in summer is $t_{\text {out }}$, the calculation formula of cooling load of the building is: 


$$
Q_{o u t}=\frac{t_{n}-t_{o u t}}{t_{n}-t_{e j}} \times Q_{e j}
$$

Where:

$Q_{\text {out }}$ Cooling load of the building when outdoor temperature is $t_{\text {out }}(\mathrm{kW} \cdot \mathrm{h})$;

$t_{n}$ _- Indoor design temperature of the building in summer $\left({ }^{\circ} \mathrm{C}\right.$ ), indoor design temperature is $25.0^{\circ} \mathrm{C}$;

$t_{e j}$ Outdoor average temperature during the test $\left({ }^{\circ} \mathrm{C}\right)$, outdoor average temperature of the project during the test is $26.0^{\circ} \mathrm{C}$;

$t_{\text {out }}$ Outdoor temperature in summer $\left({ }^{\circ} \mathrm{C}\right)$;

$Q_{e j}$ Cooling load of the building when outdoor average temperature is $t_{e j}(\mathrm{~kW} \cdot \mathrm{h})$.

The refrigeration consumption of the building in certain temperature frequency can be determined according to Formula (2). The specific results are shown in Table 5.

Table 5 Refrigeration Consumption of the Building under Different Temperature Frequency

\begin{tabular}{|c|c|c|c|c|}
\hline $\mathrm{BIN} /{ }^{\circ} \mathrm{C}$ & 24 & 26 & 28 & 30 \\
\hline $\begin{array}{c}\text { Time } \\
\text { frequency/h }\end{array}$ & 472 & 507 & 400 & 252 \\
\hline $\begin{array}{c}Q_{\text {out }} \\
/ \mathrm{kW} \cdot \mathrm{h}\end{array}$ & $/$ & 817.7 & 2453.1 & 4088.5 \\
\hline $\mathrm{BIN} /{ }^{\circ} \mathrm{C}$ & 32 & 34 & 36 & $/$ \\
\hline $\begin{array}{c}\text { Time } \\
\text { frequency/h }\end{array}$ & 126 & 46 & 16 & $/$ \\
\hline $\begin{array}{c}Q_{\text {out }} \\
/ \mathrm{kW} \bullet \mathrm{h}\end{array}$ & 5723.9 & 7359.3 & 8994.7 & $/$ \\
\hline $\begin{array}{c}\text { Total accumulative refrigeration } \\
\text { consumption } Q_{L} / \mathrm{kW} \cdot \mathrm{h}\end{array}$ & 3629770.3 \\
\hline
\end{tabular}

\section{B. Calculation of energy-saving benefit}

Calculate out annual energy consumption of the project through different air conditioning heating modes according to annual heat consumption and refrigeration consumption and heat value and price of different energy in the project. The specific calculation results are shown in Table 6 and Table 7.
Table 6 Energy Saving Quantity Analysis of Ground Source Heat Pump Air Conditioning System

\begin{tabular}{|l|c|l|c|}
\hline System form & $\begin{array}{l}\text { Ground source } \\
\text { heat pump air } \\
\text { conditioning } \\
\text { system }\end{array}$ & $\begin{array}{l}\text { Conventional } \\
\text { refrigeration } \\
\text { and } \\
\text { air-conditioning } \\
\text { system }\end{array}$ & $\begin{array}{l}\text { Central } \\
\text { heating of } \\
\text { coal-fired } \\
\text { boiler }\end{array}$ \\
\hline $\begin{array}{l}\text { Power } \\
\text { consumption in } \\
\text { winter/kW•h }\end{array}$ & 1253641 & $/$ & $/$ \\
\hline $\begin{array}{l}\text { Power } \\
\text { consumption in } \\
\text { summer/kW•h }\end{array}$ & 881012 & 1396065 & $/$ \\
\hline $\begin{array}{l}\text { Standard coal } \\
\text { consumption in } \\
\text { winter/t }\end{array}$ & $/$ & $/$ & 655.6 \\
\hline $\begin{array}{l}\text { Equate to } \\
\text { standard coal/t }\end{array}$ & 768.5 & 502.6 & 655.6 \\
\hline $\begin{array}{l}\text { Coal conservation of ground source heat pump air } \\
\text { conditioning system/t }\end{array}$ & 389.7 \\
\hline
\end{tabular}

1. Calculate annual power consumption of heat pump air conditioning system according to its estimated results of average energy efficiency ratio and load during test period in winter. The calculation formula is : $E_{h}=\frac{Q_{h}}{C O P_{S H}}$;

2. Calculate annual power consumption of heat pump air conditioning system according to its estimated results of average energy efficiency ratio and load during test period in summer. The calculation formula is: $E_{l}=\frac{Q_{L}}{C O P_{s}}$;

3. Energy consumption calculation formula of conventional water chiller air conditioning system is: $E_{l c}=\frac{Q_{l}}{C O P_{s l c}}$

Where:

$E_{l c}$ - Power consumption of conventional air conditioning system in cooling season $(\mathrm{kW} \cdot \mathrm{h})$;

Notes

$Q_{L}$-Accumulative cooling load of the building in cooling season $(\mathrm{kW} \cdot \mathrm{h})$;

$\mathrm{COP}_{\text {slc }}$ —Energy efficiency ratio of conventional air conditioning system during refrigeration, When the unit capacity is $528 \sim 1163 \mathrm{~kW}$, the ratio is 2.60 .

4. Energy consumption calculation formula of coal-fired boiler room is: $Q_{t c}=\frac{Q_{h}}{\eta q}$

Where:

$Q_{t c} \longrightarrow$ Standard coal consumption of coal-fired boiler room in heating season $(\mathrm{t})$;

$Q_{h}$ _ Accumulative heating load of the building in heating season $(\mathrm{kW} \bullet \mathrm{h})$;

$\eta$ — Heating operation efficiency of the boiler, it is 0.7 ;

$q$ - Heat value of standard coal $(\mathrm{kW} \cdot \mathrm{h} / \mathrm{t})$, it is $8141 \mathrm{~kW} \cdot \mathrm{h} / \mathrm{t}$.

5. Per kilowatt hour is converted to $0.36 \mathrm{~kg}$ standard coa consumption. 
Table 6 shows that ground source heat pump air conditioning system can save 389.7t standard coal every year compared with coal boiler heating system plus conventional refrigeration and air-conditioning system. Energy saving rate reaches $33.6 \%$.

Table 7 Economic Analysis of Ground Source Heat Pump Air Conditioning System

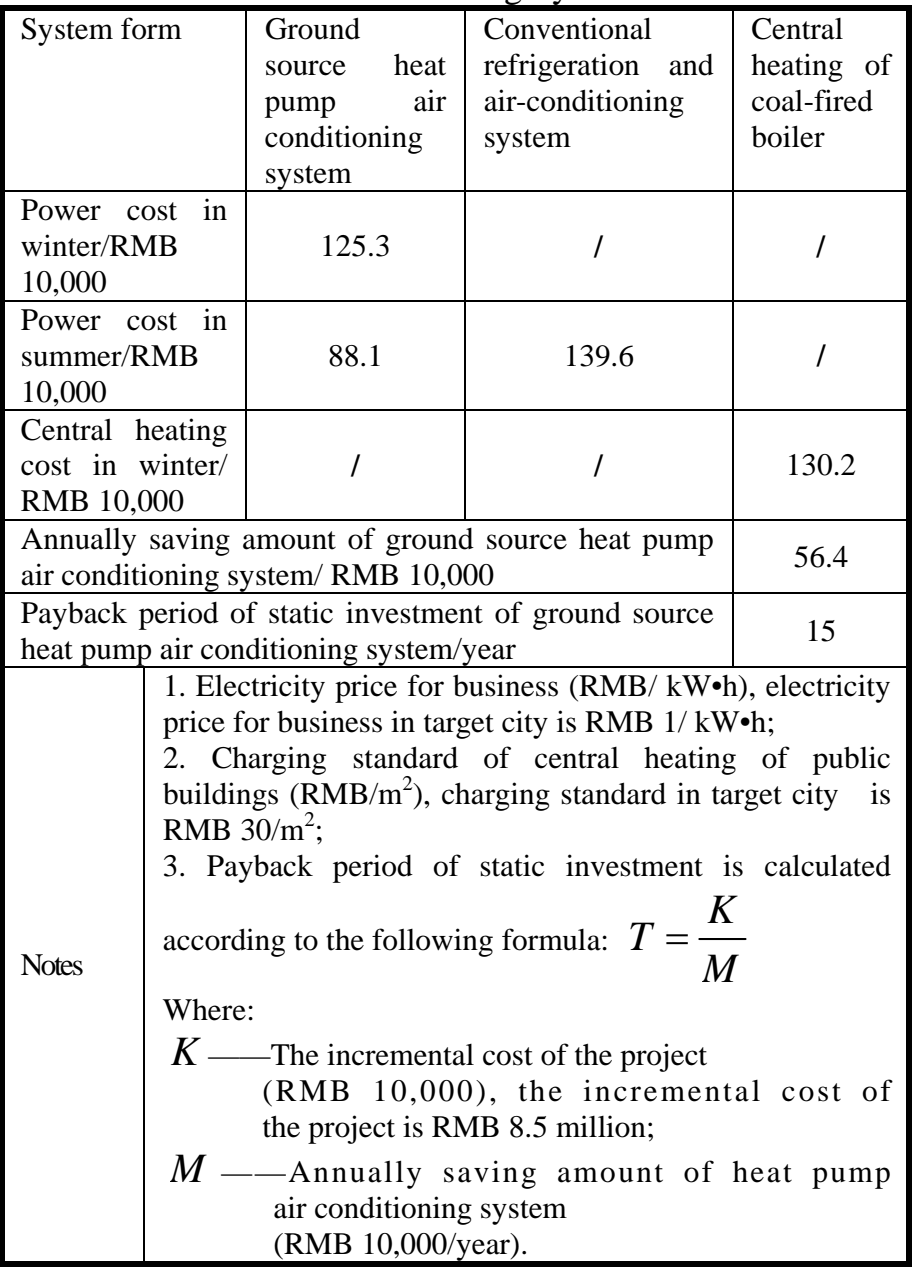

Table 7 shows that ground source heat pump air conditioning system can save RMB 564,000 every year compared with coal boiler heating system plus conventional refrigeration and air-conditioning system. Payback period of static investment is 15 years.

\section{Conclusion}

In this paper, the technology and economy of the project is analyzed through combining test data of ground source heat pump air conditioning system. The research results have shown:

1) The operation effect of the project is good. The system can satisfy the load demand of air conditioning terminal device in heating and cooling season;

2) The energy-saving benefit of the project is remarkable. The energy saving rate reaches 33.6\%;

3) The project has certain economic benefit. Certain cost can be saved every year. However, payback period of static investment is long. It can be completed just within the equipment life cycle.

4) The operation condition such as large flow and little difference in temperature exists in heat pump air conditioning system during the test. Thus, try to further consider optimal operation scheme. In addition, the project is input for a short time; the occupancy is not high and the load is low. These reasons lead to bad economic benefit. If better optimal operation is realized and the occupancy is improved, energy saving and economic benefit of the project will be further improved.

\section{Acknowledgements}

This work was supplied by Provincial Science and technology project (2013GSF11612), China.

\section{References}

[1] Documents of Ministry of Housing and Urban-Rural Development. The Notice for Issuing Technical Guide of Data Monitoring System of Renewable Energy in Construction Application Demonstration Project (trial implementation) by Ministry of Housing and Urban-Rural Development and Department of Science \& Technology (JKJH [2009] No. 146 ) [K].2006.

[2] Documents of Ministry of Finance and Ministry of Housing and Urban-Rural Development.The Notice for Speeding up Acceptance and Assessment of Renewable Energy Construction Application Demonstration Project (CBJ [2009] No. 116) [K].2009.

[3] JGJ/T 177-2009. Energy Saving Test Standard of Public Buildings [S].Beijing: China Architecture \& Building Press, 2010

[4] GB/T 50801-2013. Evaluation Standard for application of renewable energy in buildings. [S].Beijing: China Architecture \& Building Press, 2013. 